\title{
DEVELOPMENT OF EDIBLE COATING WITH SPIRULINA PLATENSIS AND BY-PRODUCTS OF CASSAVA AND ORANGE
}

\author{
Taís Cardoso $^{1 凶}$, Liscristiane Ferreira Fabro ${ }^{1}$, Beatriz Cervejeira Bolanho ${ }^{2}$, Ivo Mottin Demiate ${ }^{1}$, \\ Eliane Dalva Godoy Danesi ${ }^{1}$
${ }^{1}$ Department of Food Engineering, State University of Ponta Grossa (UEPG), 84030-900, Ponta Grossa, PR, Brasil.
${ }^{2}$ Department of Technology, State University of Maringá (UEM), 87506-370, Umuarama, PR, Brasil. $凶_{\text {taaiscardoso33@gmail.com }}$

https://doi.org/10.34302/crpifst/2020.12.1.2

\begin{tabular}{|c|c|}
\hline Article history: & ABSTRACT \\
\hline Received: & The use of by-products from orange and cassava processing and the \\
\hline 14 January 2019 & Spirulina platensis biomass was studied to prepare edible coating, using a \\
\hline Accepted: & Simplex-Centroid design. The formulations were evaluated regarding \\
\hline 1 February 2020 & physical, optical, solubility and barrier properties. There was no significant \\
\hline Keywords: & difference among the samples in relation to water activity, grammage and \\
\hline Active packaging; & swelling in acid solution $(30 \mathrm{~min})(\mathrm{p}>0.10)$. The addition of $S$. platensis \\
\hline Optical properties; & caused lower rates of swelling in $\mathrm{NaHCO}_{3}$ solution. The cassava bagasse \\
\hline Permeability; & incorporation affected positively the density, which can be related to the \\
\hline Solubility; & starch content of this by-product. The ternary mixture of the components \\
\hline Microalgae. & $\begin{array}{l}\text { studied had the highest values for the color parameter } \mathrm{a}^{*} \text {. The results showed } \\
\text { potential application of the films produced in dehydrated and green products. }\end{array}$ \\
\hline
\end{tabular}

\section{Introduction}

Population growth has triggered investigations into sustainable alternatives to meet the increasing need for food, mitigate losses and maximize the use of raw materials so as to value production chains. The researches on edible coating have been motivated by both increasing consumer demand for safe, convenient and stable foods (Konuk Takma and Korel, 2019). Edible coatings perform multiple functions; they may avoid moisture migration (active packaging), create barriers against external elements, retain aromatic compounds, improve mechanical characteristics of foods providing structural integrity - and they have antioxidant and antimicrobial potential (Basumatary et al., 2018; Hanani, Yee and NorKhaizura, 2019). In order to improve coating performance, applicability and functionality, several composites have been developed through fiber reinforcement (Sobral, 2015).
Interaction among components of the formulations reflects on the final properties of the resulting matrices (Brodhagen et al., 2015).

Starch has been the most common raw material used for making edible coatings due to its availability, biodegradability, even though it has high hygroscopicity. Otherwise, agroindustrial by-products have become promising alternatives as materials for coating production making possible the valorization of productive chains with sustainable technologies (Dantas et al., 2015; Sobral, 2015). Brazil is the largest producer of orange and the second largest producer of cassava worldwide, which generates high amounts of by-products after juice and starch production, respectively (Bussolo et al., 2018). The use of cassava bagasse is interesting due to its high starch content, while the flour produced from orange albedo has high pectin content (Maria et al., 2012). Both by-products are rich in polymeric materials and have 
potential film forming properties (Bussolo et al., 2018). Addition of $S$. platensis may be original since this biomass has effects on health promotion and its antioxidant and antimicrobial activity, however, its behavior in the edible coating production must be evaluated (Lanlan $e t$ al., 2015). The aim of this study was to develop edible coatings using cassava and orange byproducts, as well as $S$. platensis, characterizing them in relation to their properties to enable their potential application.

\section{Materials and methods}

The components used in the edible coating production were: cassava starch $\left(\right.$ Yoki $^{\circledR}$, Paranavaí, Paraná, Brazil), commercial $S$. platensis (Fazenda Tamanduá ${ }^{\circledR}$ 0023/2014, Santa Terezinha, Paraíba, Brazil) cassava bagasse supplied by Lorenz ${ }^{\circledR}$ (a cassava processing industry located in Umuarama, Paraná, Brazil), orange bagasse (obtained in the food engineering laboratory of the State University of Ponta Grossa/ Brazil from orange albedo after juice extraction), glycerol (P.A Reactif () and water. The by-products were submitted to dehydration in an oven (Tecnal TE$394 / 2$, Piracicaba, Brazil) at $60{ }^{\circ} \mathrm{C}$ for $24 \mathrm{~h}$. The dried materials were grinded in a mill (Ika Werke M20, Wilmington, USA) and the particle size separation was performed through metallic sieves (Bertel, Caieiras, Brazil). For characterization analyses were used anhydrous calcium chloride $\left(\mathrm{CaCl}_{2}\right)$, sodium chloride $(\mathrm{NaCl})$, hydrochloric acid $(\mathrm{HCl})$ and sodium bicarbonate $\left(\mathrm{NaHCO}_{3}\right)$.

The Simplex-Centroid design was chosen for planning with three components, resulting in 10 experiments. The coating formulations were produced using the mixture of S. platensis (X1), cassava bagasse (X2), orange bagasse (X3) totalizing 2\% (Table 1), cassava starch (4\%), glycerol $(1 \%)$ and water to bring the volume to $100 \%$. The fixed concentrations of starch and glycerol were established in preliminary tests. Coatings solutions were obtained by casting, which consists of dispersion, solubilization and gelatinization in the solvent of the raw materials (Lopes et al., 2014). Formulations were placed in the RVA (Rapid Visco Analyser ${ }^{\circledR}$, Newport Scientific, Narabeen, Australia), where gelatinization took place at temperatures from $45^{\circ} \mathrm{C}$ to $90^{\circ} \mathrm{C}$, for $13 \mathrm{~min}$, at constant mechanical stirring (160 rpm). After processing, the solutions were poured on acrylic plates and placed in a forced-air oven (Tecnal TE-394/2, Piracicaba, São Paulo, Brazil) at $42^{\circ} \mathrm{C}$ for $3 \mathrm{~h}$. After drying, the coatings were put in a desiccator with $\mathrm{NaCl}$-saturated environment ( $75 \% \mathrm{RU})$ at room temperature (Maria et al., 2012).

Table 1. Simplex-Centroid Design increased to mix components to edible coatings formulation

\begin{tabular}{|c|c|c|c|c|c|c|}
\hline Formulation & \multicolumn{3}{|c|}{ Coded variables } & \multicolumn{3}{c|}{ Real variables (g/100 g) } \\
\hline & $\mathrm{S}$ & $\mathrm{CB}$ & $\mathrm{OB}$ & $\mathrm{S}$ & $\mathrm{CB}$ & $\mathrm{OB}$ \\
\hline $\mathrm{A}$ & 1.00 & 0.00 & 0.00 & 2 & 0 & 0 \\
\hline $\mathrm{B}$ & 0.00 & 1.00 & 0.00 & 0 & 2 & 0 \\
\hline $\mathrm{C}$ & 0.00 & 0.00 & 1.00 & 0 & 0 & 2 \\
\hline $\mathrm{D}$ & 0.50 & 0.50 & 0.00 & 1 & 1 & 0 \\
\hline E & 0.50 & 0.00 & 0.50 & 1 & 0 & 1 \\
\hline F & 0.00 & 0.50 & 0.50 & 0 & 50 & 50 \\
\hline G & 0.66 & 0.17 & 0.17 & 1.32 & 0.34 & 0.34 \\
\hline $\mathrm{H}$ & 0.17 & 0.66 & 0.17 & 0.3417 & 1.3266 & 0.3417 \\
\hline
\end{tabular}




\begin{tabular}{|c|c|c|c|c|c|c|}
\hline I & 0.17 & 0.17 & 0.66 & 0.3417 & 0.3417 & 1.32 \\
\hline J & 0.33 & 0.33 & 0.33 & 0.66 & 0.66 & 0.66 \\
\hline
\end{tabular}

Note: S - Spirulina platensis; CB - cassava bagasse; OB - orange bagasse

The moisture was determined according to Ghasemlou et al. (2011). The water activity $\left(\mathrm{A}_{\mathrm{w}}\right)$ was analyzed by Aqualab3 TE (Decagon, Aqualab Inc, Pullman, WA, USA). Density was evaluated as the ratio between the mass and the volume of the coating. The thickness was measured by a digital micrometer (Mitutoyo, Tokyo, Japan). Grammage was determined by the ratio between the mass and the area of the material under analysis, while the final result was obtained by calculating the mean of the triplicates (Sobral, 1999).

Samples of the same size obtained through the use of a caliper, which had been previously dried, were immersed in distilled water $(50 \mathrm{~mL})$ and agitated for $24 \mathrm{~h}$ at room temperature (25 $\left.{ }^{\circ} \mathrm{C}\right)$. The solubilized mass was quantified by filtration of the solution, dried in an oven at 105 ${ }^{\circ} \mathrm{C}$ (Nova Ética ${ }^{\circledR}$, Botucatu, São Paulo, Brazil) for $24 \mathrm{~h}$ and, then, weighed (Gontard et al., 1992). Edible coating solubility in water (MS) was expressed as percentage, as shown by Equation 1, where $\mathrm{M}_{\text {initial }}$ is the amount of initial dry material and $\mathrm{M}_{\text {final }}$ is the dry mass after a $24-$ hour period.

$$
M S=\frac{(\text { M initial }-\mathrm{M} \text { final })}{\text { M initial }} X 100 \text { (Eq. 1) }
$$

The water vapor permeability was determined gravimetrically, according to the ASTM E96 test, which was used by Duong et al. (2015). About $5 \mathrm{~g}$ of anhydrous calcium chloride was placed into a glass container called permeability capsule. The container was then sealed with the edible coating whose area was $0.00144545 \mathrm{~m}^{2}$. Capsules were stored in a desiccator whose relative humidity was $75 \%$ (saturated solution of $\mathrm{NaCl}$ ). The desiccator was kept in an BOD incubator (Tecnal, Piracicaba, São Paulo, Brazil) at $25^{\circ} \mathrm{C}$. Moisture gain in grams (W) was determined by successive weighing every $24 \mathrm{~h}$. Saturation pressure of water vapor $(\Delta \mathrm{P})$ at $25^{\circ} \mathrm{C}$ was expressed as Pascal (Pa). Permeability was calculated by Equation 2.

$$
\text { Permeability }=\frac{(\mathrm{W} \times \mathrm{T})}{(\mathrm{A} \times \Delta \mathrm{P})}(\text { Eq. } 2)
$$

Color determination was carried out by a direct reading colorimeter (Hunterlab, Miniscan EZ, Reston, VA, USA) in the central part of the material. Equal-area samples of edible coating were immersed into an acid solution $(\mathrm{HCl}, \mathrm{pH}$ 1.8) and into an alkaline solution $\left(\mathrm{NaHCO}_{3}, \mathrm{pH}\right.$ 8.3). Samples were withdrawn every 10, 30 and $60 \mathrm{~min}$, removing the excess of solution with absorbent paper, and after they were weighed. Quantification of swelling was made by using the Equation 3, where SI (\%) is the swelling index, Wi is the weight of the wet film and Ws is the weight of the dry coating.

$$
\frac{\mathrm{SI}=(\mathrm{Wi}-\mathrm{Ws})}{\mathrm{Ws}} X 100 \text { (Eq. 3) }
$$

Mechanical tests were performed in triplicate, with adaptations of the method described by De Carvalho and Grosso, (2004). Maximum tensile strength (MPa) and elongation at break (\%) were determined using a Shimadzu $^{\circledR}$ AG-I 10KN (Shimadzu, Kyoto, Japan) operating according to the standard method ASTM D882-02, with adaptations. The films were cut forming specimens of $0.10 \mathrm{~m}$ in length and $0.025 \mathrm{~m}$ in width, suffering a traction at a speed of $8 \times 10^{-4} \mathrm{~m} / \mathrm{s}$, and the initial distance between the clamps being $0.050 \mathrm{~m}$. The breaking stress can be calculated from Equation 4 and the breaking elongation according to Equation 5:

Tensile maximum strength $=\frac{F_{\max }}{A_{\min }}($ Eq. 4)

Where: 
$\mathrm{F}_{\max }=$ maximum force $(\mathrm{N})$

$\mathrm{A}_{\min }=$ minimum initial sample area $\left(\mathrm{mm}^{2}\right)$.

Elongation at break $=\frac{\mathrm{Ar}}{\mathrm{DG}} \times 100$

(Eq. 5)

Where:

$\mathrm{Ar}=$ elongation $(\mathrm{mm})$

$\mathrm{DG}=$ initial distance between clamps $(\mathrm{mm})$

Statistical tests were performed to verify both normality of data (Kolmogorov-Smirnov) and homogeneity of variance (Levene). Data were adjusted to obtain the mathematical model and submitted to the analysis of variance (ANOVA), at $90 \%$ level of significance, to check the statistical difference between the samples and the model significance. The general equation for modeling can be seen in Equation 6 , where $\mathrm{Y}$ is the estimated response, $\beta 1, \beta 2$ and $\beta 3$ are the regression coefficients for the linear model, $\beta 12, \beta 13$ and $\beta 23$ are the regression coefficients for the quadratic model and $\beta 123$ for the special cubic model. The quality of the adjustment was measured by the normality of residues (Kolmogorov-Smirnov). Response surfaces and their mathematical model that do not represent the totality of the data ( $\mathrm{R} 2$ value below 0.7) are not shown. In the equations it was used $\mathrm{S}$ for $S$. platensis (X1), CB for cassava bagasse (X2) and OB (X3) for orange bagasse.

$$
\begin{gathered}
\mathrm{Y}=\beta 1 \mathrm{X} 1+\beta 2 \mathrm{X} 2+\beta 3 \mathrm{X} 3+ \\
\beta 12 \mathrm{X} 1 \mathrm{X} 2+\beta 13 \mathrm{X} 1 \mathrm{X} 3+\beta 23 \mathrm{X} 2 \mathrm{X} 3+ \\
\beta 123 \mathrm{X} 1 \mathrm{X} 2 \mathrm{X} 3 \quad \text { (Eq. 6) }
\end{gathered}
$$

\section{Results and discussions}

Moisture analysis is fundamental to understand the coating behavior, since low water contents may form brittle coatings whereas high water contents may develop an environment which favors microbial growth. In this study, moisture ranged between 11.69 and $16.31 \mathrm{~g} / 100$ g (Table 2).
This parameter was adjusted to obtain the corresponding mathematical model (Eq. 7) and the contour plot (Figure 1A). The model was adjusted and followed normal distribution of data $(p=0.29)$. The contour plot confirms the tendency that moisture has to increase due to the presence of orange bagasse.

$$
\begin{gathered}
\text { Moisture }=13.18(\mathrm{~S})+13.81(\mathrm{CB})+ \\
\text { 17.95(OB) }-12.40(\mathrm{~S} . \mathrm{CB})- \\
14.16(\mathrm{~S} . \mathrm{OB})-9.40(\mathrm{CB} . \mathrm{OB})+ \\
\text { 68.35(S. CB. OB) }(\text { Eq. } 7)
\end{gathered}
$$

The water activity values ranged from 0.59 to 0.61 , with no significant difference among the formulations. According to Corrêa et al. (2001), values below 0.80 decrease the velocity of most enzyme reactions as well as growth inhibition of fungi and pathogens.

The use of cassava bagasse affected positively the density of the formulations studied. This by-product, obtained after starch extraction, has high percentage of starch (64\%) (Dos Santos Abrahão, Do Prado, Marques, Perotto, \& Bernardo Lugão, 2006), depending on the efficiency of the extraction process and it has lower fiber content than that found in orange bagasse (78\%) (Neres et al., 2016). It is known that high amounts of fiber form films with low densities, i. e., low compaction, which enables empty spaces to form (Wollerdorfer and Bader, 1998).

The velocity at which solvents disseminate into the polymeric matrix depends on the compaction level of the chains and on the number of molecules of the permeate. Therefore, the increase in density may be related to the high molar mass of starch (Almeida, Woiciechowski, Wosiacki, Prestes, \& Pinheiro, 2013). This parameter may be associated with the moisture content of coatings, as shown in Table 2. Low densities enabled higher moisture permeation into intermolecular empty spaces. Denser films have higher grammage, making the polymeric matrix more compact and less permeable. The parameter density was adjusted to obtain the corresponding mathematical model (Eq. 8) and the contour plot (Figure 1B). 
Density $=0.99(\mathrm{~S})+0.91(\mathrm{CB})+$ $0.74(\mathrm{OB})+1.45(\mathrm{~S} . \mathrm{CB})+0.59(\mathrm{~S} . \mathrm{OB})-$ $0.41($ CB. OB) -9.1 (S. OB. CB $)+$ 1.59 (S. CB). (S - CB) - 1.8(S. OB). (S - OB) (Eq. 8)
The model of the parameter density explains $97.5 \%$ of the data. There is no lack of adjustment, a fact that can be confirmed by the normal distribution of residues $(\mathrm{p}=0.880)$. The contour plot (Figure 1B) illustrates the data shown in Table 2.

Table 2.Moisture, water activity, density, thickness and grammage of coating formulations

\begin{tabular}{|c|c|c|c|c|}
\hline Formulation & Moisture (g/100 g) & Aw & Density $\left(\mathrm{x} 10^{3} \mathrm{~kg} / \mathrm{m}^{3}\right)$ & Thickness $\left(\mathrm{x} 10^{-3} \mathrm{~m}\right)$ \\
\hline A & $14.84 \pm 2.38^{\mathrm{abc}}$ & $0.61 \pm 0.10$ & $0.88 \pm 0.13^{\mathrm{a}}$ & $0.25 \pm 0.03^{\mathrm{e}}$ \\
\hline $\mathrm{B}$ & $11.69 \pm 1.27^{\mathrm{d}}$ & $0.60 \pm 0.00$ & $1.01 \pm 0.29^{\mathrm{a}}$ & $0.23 \pm 0.03^{\mathrm{e}}$ \\
\hline $\mathrm{C}$ & $14.17 \pm 2.21^{\mathrm{bc}}$ & $0.59 \pm 0.30$ & $0.86 \pm 0.11^{\mathrm{a}}$ & $0.26 \pm 0.06^{\mathrm{e}}$ \\
\hline $\mathrm{D}$ & $13.58 \pm 1.29^{\mathrm{cd}}$ & $0.59 \pm 0,00$ & $0.82 \pm 0.11^{\mathrm{ab}}$ & $0.25 \pm 0.02^{\mathrm{e}}$ \\
\hline $\mathrm{E}$ & $14.80 \pm 2.38^{\mathrm{abc}}$ & $0.58 \pm 0.00$ & $0.44 \pm 0.06^{\mathrm{d}}$ & $0.42 \pm 0.05^{\mathrm{a}}$ \\
\hline $\mathrm{F}$ & $16.31 \pm 1.08^{\mathrm{a}}$ & $0,59 \pm 0.00$ & $0.65 \pm 0.15^{\mathrm{bc}}$ & $0.30 \pm 0.04^{\mathrm{cd}}$ \\
\hline $\mathrm{G}$ & $14.89 \pm 0.70^{\mathrm{abc}}$ & $0.59 \pm 0.1$ & $0.49 \pm 0.09^{\mathrm{cd}}$ & $0.35 \pm 0.04^{\mathrm{bc}}$ \\
\hline $\mathrm{H}$ & $15.73 \pm 2.21^{\mathrm{ab}}$ & $0.59 \pm 0.0$ & $0.57 \pm 0.04^{\mathrm{cd}}$ & $0.34 \pm 0.04^{\mathrm{abc}}$ \\
\hline I & $15.37 \pm 0.70^{\mathrm{abc}}$ & $0.58 \pm 0.01$ & $0.62 \pm 0.13^{\mathrm{cd}}$ & $0.40 \pm 0.05^{\mathrm{ab}}$ \\
\hline $\mathbf{J}$ & $15.45 \pm 0.23^{\mathrm{abc}}$ & $0.59 \pm 0.00$ & $0.57 \pm 0.08^{\mathrm{cd}}$ & $0.27 \pm 0.04^{\mathrm{e}}$ \\
\hline $\mathrm{P}$ value $(* \mathrm{~K}-\mathrm{S})$ & 0.25 & $<0.01$ & 0.57 & 0.19 \\
\hline $\mathrm{P}$ value $(* *$ Levene) & 0.78 & 0.55 & 0.61 & 0.96 \\
\hline $\mathrm{P}$ value (ANOVA) & 0.04 & $0.15 * * *$ & $<0.01$ & $<0.01$ \\
\hline $\mathrm{P}(* * * * \mathrm{~K}-\mathrm{S})$ & 0.29 & - & 0.88 & 0.49 \\
\hline Formulation & Grammage $\left(\mathrm{kg} / \mathrm{m}^{2}\right)$ & \multicolumn{2}{|c|}{ WVP (g.m/m².h.Pa) } & Solubility $(\mathrm{g} / 100 \mathrm{~g})$ \\
\hline $\mathrm{A}$ & $0.15 \pm 0.03$ & \multicolumn{2}{|c|}{$8.12 .10^{-7} \pm 2.45 .10^{-8 b d}$} & $31.76 \pm 9.66^{\mathrm{abcd}}$ \\
\hline $\mathrm{B}$ & $0.16 \pm 0.02$ & \multicolumn{2}{|c|}{$6.14 .10^{-7} \pm 6.83 .10^{-8 d}$} & $34.54 \pm 2.47^{\mathrm{ab}}$ \\
\hline $\mathrm{C}$ & $0.13 \pm 0.02$ & \multicolumn{2}{|c|}{$1.37 .10^{-6} \pm 1.60 .10^{-7 a}$} & $38.59 \pm 3.32^{\mathrm{a}}$ \\
\hline $\mathrm{D}$ & $0.14 \pm 0.01$ & \multicolumn{2}{|c|}{$5.78 .10^{-7} \pm 4.49 .10^{-8 d}$} & $32.58 \pm 1.47^{\mathrm{abcd}}$ \\
\hline $\mathrm{E}$ & $0.14 \pm 0.01$ & \multicolumn{2}{|c|}{$1.09 .10^{-6} \pm 2.63 .10^{-8 a b c}$} & $33.55 \pm 7.91^{\mathrm{abc}}$ \\
\hline $\mathrm{F}$ & $0.12 \pm 0.02$ & \multicolumn{2}{|c|}{$1.06 .10^{-6} \pm 2.45 .10^{-7 a b c}$} & $31.49 \pm 6.47^{\mathrm{abcd}}$ \\
\hline $\mathrm{G}$ & $0.12 \pm 0.00$ & \multicolumn{2}{|c|}{$1.32 .10^{-6} \pm 3.75 .10^{-7 \mathrm{a}}$} & $26.68 \pm 2.84^{\text {cde }}$ \\
\hline $\mathrm{H}$ & $0.13 \pm 0.03$ & \multicolumn{2}{|c|}{$1.10 .10^{-6} \pm 4.39 .10^{-7 a b c}$} & $24.10 \pm 4.84^{\mathrm{e}}$ \\
\hline I & $0.13 \pm 0.03$ & \multicolumn{2}{|c|}{$9.41 .10^{-7} \pm 2.66 .10^{-8 \mathrm{bcd}}$} & $25.88 \pm 3.16^{\mathrm{de}}$ \\
\hline
\end{tabular}




\begin{tabular}{|c|c|c|c|}
\hline $\mathrm{J}$ & $0.12 \pm 0.01$ & $1.28 .10^{-6} \pm 2.13 .10^{-7 \text { ac }}$ & $27.96 \pm 1.81^{\text {bcde }}$ \\
\hline P value $(* \mathrm{~K}-\mathrm{S})$ & 0.01 & 0.82 & 0.30 \\
\hline $\mathrm{P}$ value $(* *$ Levene) & 0.63 & 0.76 & 0.78 \\
\hline $\mathrm{P}$ value $($ ANOVA) & $0.48^{* * *}$ & 0.01 & 0.06 \\
\hline $\mathrm{P}(* * * \mathrm{~K}-\mathrm{S})$ & - & 0.18 & 0.87 \\
\hline
\end{tabular}

Note: *Normality test; **Homoscedasticity test; ***Non-parametric Kruskal-wallis test $(\mathrm{p}<0.10)$; **** Normality of residues; Different letters in the same column represent a significant difference according to the Fisher LSD test $(\mathrm{p}<0.10)$.

The thickness values ranged from 0.23 to $0.42 \times 10^{-3} \mathrm{~m}$ in the edible coatings produced. Lower value was found in a ternary mix studying composed of protein/chitosan/ sunflower oil $\left(0.0581 \times 10^{-3} \mathrm{~m}\right)$ (Abugoch, Tapia, Plasencia, Pastor, \& Escalona, 2015). The samples presented significant difference between them $(p<0.10)$ and the data were adjusted to obtain a mathematical model (Eq. 9) and representative response surface (Figure 1C).

Thickness $=$

$$
-2.43(\mathrm{~S})-2.22(\mathrm{CB})-2.43(\mathrm{OB})-
$$$$
1.38(\mathrm{~S} . \mathrm{CB})+0.79(\mathrm{~S} . \mathrm{OB})-
$$$$
0.89 \text { (CB. OB) - 1.98(S. CB. OB) - }
$$

1.22 (S. CB). $(\mathrm{S}-\mathrm{CB})+7.52$ (S. CB). $(\mathrm{S}-$

$$
\text { CB) (Eq. 9) }
$$

High grammage result in high tensile strength which is desirable when coatings wrap food that is sensitive to handling (Aloui, Khwaldia, Slama, \& Hamdi, 2011). However, the values found in this study did not show any significant difference $(\mathrm{p}<0.10)$. Consequently, the model could not be adjusted. Henrique et al. (2008) reported that coatings made from modified cassava starch had grammage values about 0.32 to $0.46 \mathrm{~kg} / \mathrm{m}^{2}$ than that found in this study.

There was a significant difference in water vapor permeability for the formulations tested, however, the model does not represent the totality of the data $\left(\mathrm{R}^{2}<0.7\right)$ and therefore the response surface and mathematical equation are not presented. Water vapor permeability in the formulations produced was lower than that found for coatings made from native cassava starch $(2 \mathrm{~g} / 100 \mathrm{~g})$ and glycerol $(1.9 \mathrm{~g} / 100 \mathrm{~g})$ (Gutiérrez, Tapia, Pérez, \& Famá, 2015).

Interaction between the by-products and the polymeric matrix generates coatings with higher porosity (empty spaces). As a result, they incorporate water easily and provide more soluble structures (Bouchonneau et al., 2010). It is a critical factor in food coating because of its susceptibility to deterioration as a consequence of moisture. The values of water solubility found by this study were similar to the values reported by Saberi et al., (2016) for coatings made from pea starch, glycerol and guar gum.

Starch films have low resistance in aqueous media, making permeability a limiting property (Woggum et al., 2015). In most of the formulations under analysis, the higher values of water vapor permeability increased solubility, as can be observed by correlation analysis $\left(\mathrm{R}^{2}=\right.$ $0.77, \mathrm{p}<0.05)$. The highest solubility was recorded for the ternary mixture with the highest proportion of cassava bagasse.

Swelling occurs when there is direct contact of the edible coating and a liquid medium. It is a relevant parameter when the material aims at application to food. It is fundamental to know the strength that the material has in solutions ( $\mathrm{Da}$ Silva, Gomes, Ricardo, \& Machado, 2016). Table 3 shows the results of swelling at different times in acid and alkaline media. 

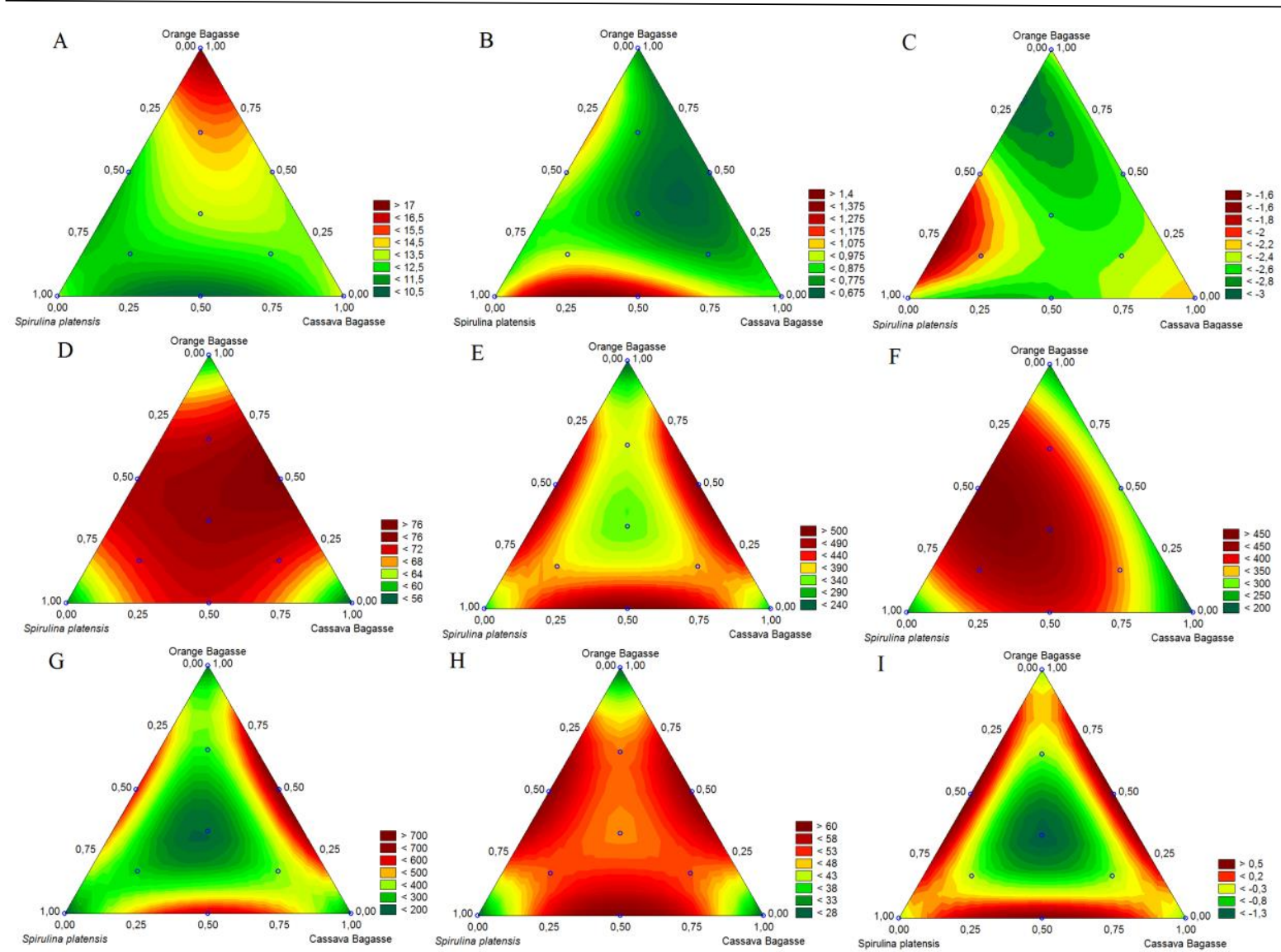

Figure 1. Response surfaces for the parameters moisture (A), density (B), thickness (C), swelling data in acid medium (SA $60 \mathrm{~min}$ ) (D), alkaline medium (SK $10 \mathrm{~min}$ ) (E), alkaline medium (SK $30 \mathrm{~min}$ ) (F), alkaline medium (SK $60 \mathrm{~min})(\mathrm{G})$, color $\mathrm{a}^{*}(\mathrm{H})$ and color $\mathrm{b}^{*}$ (I) of formulations under investigation

Table 3. Swelling index in alkaline and acid media of coating formulations under study

\begin{tabular}{|c|c|c|c|}
\hline Formulation & $\mathrm{S}_{\mathrm{HCl}}(\%) 10 \mathrm{~min}$ & $\mathrm{~S}_{\mathrm{HCl}}(\%) 30 \mathrm{~min}$ & $\mathrm{~S}_{\mathrm{HCl}}(\%) 60 \mathrm{~min}$ \\
\hline A & $282.93 \pm 18.53^{\mathrm{cd}}$ & $433.18 \pm 57.45$ & $634.88 \pm 35.71^{\mathrm{f}}$ \\
\hline B & $458.18 \pm 38.35^{\mathrm{ab}}$ & $563.65 \pm 19.49$ & $1007.35 \pm 65.92^{\mathrm{bc}}$ \\
\hline C & $304.45 \pm 23.66^{\mathrm{c}}$ & $343.55 \pm 18.34$ & $1173.29 \pm 13.84^{\mathrm{a}}$ \\
\hline $\mathrm{D}$ & $408.93 \pm 29.12^{\mathrm{b}}$ & $475.25 \pm 28.55$ & $824.76 \pm 4.48^{\mathrm{d}}$ \\
\hline E & $253.11 \pm 25.26^{\mathrm{d}}$ & $386.29 \pm 5.69$ & $795.28 \pm 23.33^{\mathrm{d}}$ \\
\hline F & $295.75 \pm 59.80^{\mathrm{c}}$ & $539.95 \pm 20.67$ & $1175.66 \pm 39.40^{\mathrm{a}}$ \\
\hline G & $517.93 \pm 46.57^{\mathrm{a}}$ & $350.19 \pm 19.48$ & $717.72 \pm 29.38^{\mathrm{e}}$ \\
\hline H & $285.62 \pm 36.14^{\mathrm{cd}}$ & $329.32 \pm 9.32$ & $1044.85 \pm 38.29^{\mathrm{b}}$ \\
\hline I & $199.78 \pm 13.97^{\mathrm{e}}$ & $568.00 \pm 2.02$ & $955.35 \pm 36.01^{\mathrm{c}}$ \\
\hline J & $419.85 \pm 18.19^{\mathrm{b}}$ & $364.09 \pm 15.84$ & $833.87 \pm 39.57^{\mathrm{d}}$ \\
\hline P value $(* K-S)$ & 0.48 & $<0.01$ & 0.13 \\
\hline P value $(* *)$ & 0.87 & 0.75 & 0.90 \\
\hline
\end{tabular}


Cardoso et al./ Carpathian Journal of Food Science and Technology, 2020, 12(1), 16-26

\begin{tabular}{|c|c|c|c|}
\hline $\mathrm{P}$ value (ANOVA) & $<0.01$ & $<0.01 * * *$ & $<0.01$ \\
\hline $\mathrm{P}(* * * * \mathrm{~K}-\mathrm{S})$ & 0.47 & 0.14 & 0.21 \\
\hline Formulation & $\mathrm{S}_{\mathrm{NaHCO} 3}(\%) 10 \mathrm{~min}$ & $\mathrm{~S}_{\mathrm{NaHCO} 3}(\%) 30 \mathrm{~min}$ & $\mathrm{~S}_{\mathrm{NaHCO} 3}(\%) 60 \mathrm{~min}$ \\
\hline A & $278.31 \pm 35.39^{\mathrm{de}}$ & $211.20 \pm 22.56^{\mathrm{ef}}$ & $219.50 \pm 17.12^{\mathrm{e}}$ \\
\hline B & $513.54 \pm 1.95^{\mathrm{a}}$ & $387.01 \pm 57.01^{\mathrm{ab}}$ & $661.51 \pm 68.40^{\mathrm{a}}$ \\
\hline $\mathrm{C}$ & $379.76 \pm 61.79^{b}$ & $435.67 \pm 38.18^{\mathrm{a}}$ & $281.81 \pm 95.06^{\mathrm{de}}$ \\
\hline $\mathrm{D}$ & $331.71 \pm 24.27^{\mathrm{bcd}}$ & $361.67 \pm 27.06^{\mathrm{bc}}$ & $415.97 \pm 107.60^{\mathrm{bc}}$ \\
\hline $\mathrm{E}$ & $307.36 \pm 28.56^{\mathrm{cd}}$ & $314.92 \pm 35.50^{\mathrm{cd}}$ & $448.70 \pm 17.91^{\mathrm{b}}$ \\
\hline $\mathrm{F}$ & $338.53 \pm 65.24^{\mathrm{bcd}}$ & $443.90 \pm 69.31^{\mathrm{a}}$ & $617.49 \pm 46.12^{\mathrm{a}}$ \\
\hline $\mathrm{G}$ & $291.24 \pm 67.84^{\mathrm{d}}$ & $266.62 \pm 57.55^{\mathrm{de}}$ & $279.63 \pm 60.70^{\mathrm{de}}$ \\
\hline $\mathrm{H}$ & $364.29 \pm 60.14^{\mathrm{bc}}$ & $292.51 \pm 51.45^{\mathrm{d}}$ & $469.81 \pm 54.34^{\mathrm{b}}$ \\
\hline I & $212.77 \pm 68.96^{\mathrm{e}}$ & $320.30 \pm 34.51^{\mathrm{bcd}}$ & $329.73 \pm 13.7^{\mathrm{cd}}$ \\
\hline $\mathrm{J}$ & $366.84 \pm 25.25^{\mathrm{bc}}$ & $186.8 \pm 431.14^{\mathrm{f}}$ & $266.62 \pm 47.87^{\mathrm{de}}$ \\
\hline $\mathrm{P}$ value $(* \mathrm{~K}-\mathrm{S})$ & 0.68 & 0.92 & 0.31 \\
\hline $\mathrm{P}$ value $(* *)$ & 0.12 & 0.93 & 0.95 \\
\hline $\mathrm{P}$ value (ANOVA) & 0.01 & $<0.01$ & $<0.01$ \\
\hline $\mathrm{P}(* * * * \mathrm{~K}-\mathrm{S})$ & 0.43 & 0.08 & 0.72 \\
\hline
\end{tabular}

Note: S - swelling; *Normality test; **Homoscedasticity test (Levene) $(\mathrm{p}<0.10) ; * * *$ Non-parametric Kruskal-Wallis test $(\mathrm{p}<0.10) ; * * * *$ Normality of residues; Different letters in the same column represent a significant difference according to the Fisher LSD test $(\mathrm{p}<0.10)$.

The comparison of treatments showed that coatings with $S$. platensis addition swelled less in alkaline medium and they were more resistant. High swelling of films with both bagasse $(\mathrm{HCl}, 60 \mathrm{~min}$, formulations $\mathrm{B}, \mathrm{C}, \mathrm{F}$ and $\mathrm{H})$ may be due to the fact that they have significant amount of fiber. When immersed into a solution, they are able to hold higher amount of solvent in their porous channels which can be filled and make the coating swell (Bouchonneau et al., 2010). Therefore, in the case of orange bagasse, which has a large amount of pectin, the swelling index is expected to be high due to its hydrophilic nature and small number of crossed bonds (Altenhofen, Cristiane, Bierhalz, \& Kieckbusch, 2009). There was no significant difference among samples in acid medium in the time of $30 \mathrm{~min}(\mathrm{p}<0.10)$. The swelling data on acid (SA $60 \mathrm{~min}$ ) and alkaline medium (SK 10,
30 and $60 \mathrm{~min}$ ) were adjusted to obtain a mathematical model (Eq. 10, 11, 12 and 13) and

response surface (Figure 1D, 1E, 1F and 1G). Equations and surfaces not shown were not representative of the data analyzed.

$$
\mathrm{SA} 60=+57.40(\mathrm{~S})+55.08(\mathrm{CB})+
$$
$58.23(\mathrm{OB})+62.17(\mathrm{~S} . \mathrm{CB})+63.50(\mathrm{~S} . \mathrm{OB})+$ 79.62(CB. OB)- 136.50(S. CB. OB) (Eq. 10)

$$
\begin{aligned}
& \text { SK } 10=+305.88(\mathrm{~S})+298.10(\mathrm{CB})+ \\
& 230.42(\mathrm{OB})+899.74(\mathrm{~S} . \mathrm{CB})+ \\
& \text { 903.26(S. OB })+
\end{aligned}
$$
1017.35(CB. OB)- 7095.92(S. CB. OB) (Eq. 11)

$$
\begin{gathered}
\text { SK } 30=+231.23(\mathrm{~S})+199.97(\mathrm{CB})+ \\
233.43(\mathrm{OB})-1.38(\mathrm{~S} . \mathrm{CB})+
\end{gathered}
$$




$$
\begin{gathered}
\text { 753.88(S. CB })+937.11(\text { S. OB })+ \\
314.30(\text { S. CB. OB) }(\text { Eq. } 12) \\
\text { SK } 60=+180.18(\text { S })+230.45(C B)+ \\
218.45(\text { OB })+1645.58(\text { S. CB })+ \\
\text { 1493.35(S. OB })+ \\
2040.32(\text { CB. OB })-15900.87 \text { (S. CB. OB })
\end{gathered}
$$$$
\text { (Eq. 13) }
$$

In relation to the color parameters (Table 4), $\mathrm{a}^{*}$ and $\mathrm{b}^{*}$ values ranged from -2.73 to 0.77 and -1.24 to 16.99 , respectively. The high starch content of cassava bagasse can interfere in the luminosity as observed in formulation B. The values found for the color parameters presented significant differences and were adjusted to obtain the corresponding mathematical model (Eq. 14 and 15) and the contour surface graph (Figure 1H and 1I). Equations and models not shown were not representative of the data $(\mathrm{R} 2<0.7)$.

$$
\begin{gathered}
\text { Parameter } \mathrm{L}=28.55(\mathrm{~S})+ \\
\text { 28.18(CB)-0.56(OB) }+27.88(\mathrm{~S} . \mathrm{CB})+ \\
\text { 143.83(S. CB })+138.12(\mathrm{~S} . \mathrm{OB})+ \\
\text { 138.71(CB. OB })-683.84(\text { S. CB. OB })(\text { Eq. } 14) \\
\text { Parameter a } *= \\
\text { 0.48(S) }-0.61(\mathrm{CB})-0.56(\mathrm{OB})+ \\
\text { 5.70(S. CB })+5.61(\mathrm{~S} . \mathrm{OB})+ \\
\text { 5.74(CB. OB })-73.12(\text { S. CB. OB })(\text { Eq. } 15)
\end{gathered}
$$

Table 4. Color parameters of coating formulations

\begin{tabular}{|c|c|c|c|}
\hline Formulation & $\mathrm{L}^{*}$ & $\mathrm{a}^{*}$ & $\mathrm{~b}^{*}$ \\
\hline A & $26.67 \pm 0.57^{\mathrm{h}}$ & $-0.60 \pm 0.08^{\mathrm{d}}$ & $13.06 \pm 0.42^{\mathrm{d}}$ \\
\hline B & $60.01 \pm 1.10^{\mathrm{a}}$ & $0.77 \pm 0.03^{\mathrm{a}}$ & $-1.24 \pm 0.23^{\mathrm{h}}$ \\
\hline C & $60.35 \pm 0.53^{\mathrm{a}}$ & $-0.30 \pm 0.01^{\mathrm{c}}$ & $2.10 \pm 0.16^{\mathrm{g}}$ \\
\hline E & $34.50 \pm 0.21^{\mathrm{f}}$ & $-1.81 \pm 0.03^{\mathrm{f}}$ & $16.99 \pm 0.07^{\mathrm{a}}$ \\
\hline F & $37.12 \pm 1.28^{\mathrm{e}}$ & $-2.32 \pm 0.09^{\mathrm{g}}$ & $16.78 \pm 0.34^{\mathrm{a}}$ \\
\hline $\mathrm{G}$ & $59.05 \pm 0.51^{\mathrm{b}}$ & $0.41 \pm 0.01^{\mathrm{b}}$ & $-0.57 \pm 0.18^{\mathrm{h}}$ \\
\hline $\mathrm{H}$ & $32.58 \pm 0.43^{\mathrm{g}}$ & $-1.58 \pm 0.18^{\mathrm{e}}$ & $15.70 \pm 1.55^{\mathrm{b}}$ \\
\hline $\mathrm{I}$ & $50.46 \pm 0.20^{\mathrm{c}}$ & $-2.48 \pm 0.06^{\mathrm{h}}$ & $11.69 \pm 0.36^{\mathrm{e}}$ \\
\hline $\mathrm{J}$ & $50.01 \pm 0.14^{\mathrm{c}}$ & $-2.51 \pm 0.01^{\mathrm{h}}$ & $9.71 \pm 0.13^{\mathrm{f}}$ \\
\hline P value(*K-S) & $43.66 \pm 0.54^{\mathrm{d}}$ & $-2.73 \pm 0.08^{\mathrm{i}}$ & $14.30 \pm 0.71^{\mathrm{c}}$ \\
\hline P value(**) & 0.03 & $<0.01$ & $<0.01$ \\
\hline P value(ANOVA) & $<0.01^{* * *}$ & $<0.01^{* * *}$ & $<0.01^{* * *}$ \\
\hline P model & 0.35 & 0.11 & 0.35 \\
\hline P (****K-S) & 0.04 & 0.02 & 0.03 \\
\hline
\end{tabular}

Note: *Normality test; **Homoscedasticity test (Levene); ***Non-parametric Kruskal-Wallis test; **** Normality of residues; Different letters in the same column represent a significant difference according to the Fisher LSD test $(\mathrm{p}<0.10)$.

S. platensis has more pigments than the byproducts used in the edible coatings production, such as chlorophyll, besides $\beta$-carotene and phycocianin (Liu, Huang, Zhang, Cai, \& Cai, 2016; Wu, Liu, Miron, Klímová, \& Wan, 2016). However, the center point corresponding to the ternary mixture showed the highest values for this color parameter (green color) as can be 
observed in Figure 1I. It can be attributed to the interaction of the components of the microalga and the by-products used in the process of coating production. The coating that presented green color has potential for application in vegetables of this color.

The films developed in this study presented a low tensile strength compared to previous study by Mohammadi et al. (2018), where the values were about 60 times higher for this parameter. However, elongation values at rupture were relatively close (3.52-39.82 \%). Data not shown indicate that the films did not have sufficient and adequate structure for this analysis.

\section{Conclusions}

In the edible coatings produced, the addition of $S$. platensis decreased the rates of swelling in $\mathrm{NaHCO}_{3}$ solution, the orange bagasse and cassava bagasse affected positively the moisture content and the density, respectively. High density results in more compact material and fewer spaces for water incorporation, a fact that enables this coating to be applied to dehydrated products. The ternary mixture of the components studied showed the highest values for the color parameter $\mathrm{a}^{*}$, suggesting their application in green vegetables and potential incorporation of bioactive compounds due to the presence of $S$. platensis. Mathematical modeling and statistical analysis of data enabled different formulations to be compared regarding several parameters. Thus, this study provided information on the interference of various components incorporated to the polymeric matrix in coating characteristics and functionality. This study gave evidence of the viability of making edible coating with cassava and orange by-products and S. platensis. It is the starting point for future works on this subject using bagasse combination. The methodology and tests for larger scales must be adapted.

\section{References}

Basumatary, K. et al. (2018) 'Lagerstroemia speciosa fruit-mediated synthesis of silver nanoparticles and its application as filler in agar based nanocomposite films for antimicrobial food packaging', Food Packaging and Shelf Life. Elsevier, 17(June), pp. 99-106. doi: 10.1016/j.fps1.2018.06.003.

Brodhagen, M. et al. (2015) 'Biodegradable plastic agricultural mulches and key features of microbial degradation', pp. 1039-1056. doi: 10.1007/s00253-014-6267-5.

Bussolo, C. et al. (2018) 'Bioactive Carbohydrates and Dietary Fibre Characterization and in vitro digestibility of by-products from Brazilian food industry: Cassava bagasse, orange bagasse and passion fruit peel', Bioactive Carbohydrates and Dietary Fibre. Elsevier Ltd, (August), pp. 1-10. doi: 10.1016/j.bcdf.2018.08.001.

De Carvalho, R. A. and Grosso, C. R. F. (2004) 'Characterization of gelatin based films modified with transglutaminase, glyoxal and formaldehyde', Food Hydrocolloids, 18(5), pp. 717-726.

Dantas, E. A. et al. (2015) 'Caracterização e avaliação das propriedades antioxidantes de fi lmes biodegradáveis incorporados com polpas de frutas tropicais', Ciência Rural, 45(1), pp. 142-148.

Hanani, Z. A. N., Yee, F. C. and Nor-Khaizura, M. A. R. (2019) 'Effect of pomegranate (Punica granatum L.) peel powder on the antioxidant and antimicrobial properties of fish gelatin films as active packaging', Food Hydrocolloids. Elsevier Ltd, 89, pp. 253259. doi: 10.1016/j.foodhyd.2018.10.007.

Konuk Takma, D. and Korel, F. (2019) 'Active packaging films as a carrier of black cumin essential oil: Development and effect on quality and shelf-life of chicken breast meat', Food Packaging and Shelf Life. Elsevier, 19(November 2018), pp. 210-217. doi: 10.1016/j.fpsl.2018.11.002.

Lanlan, Z. et al. (2015) 'Bioresource Technology Attached cultivation for improving the biomass productivity of Spirulina platensis', Bioresource Technology. Elsevier Ltd, 181, pp. 136-142. doi: 10.1016/j.biortech.2015.01.025.

Maria, S. et al. (2012) 'Propriedades físicas de 
filmes comestíveis a base de proteínas miofibrilares de carne bovina Physical properties of edible films based on bovine myofibril proteins', pp. 283-296. doi: 10.5433/1679-0359.2012v33n1p283.

Mohammadi, R. et al. (2018) 'Physicomechanical and structural properties of eggshell membrane gelatin- chitosan blend edible films', International Journal of Biological Macromolecules. Elsevier B.V., 107(PartA), pp. 406-412. doi: 10.1016/j.ijbiomac.2017.09.003.

Saberi, B. et al. (2016) 'Optimization of physical and optical properties of biodegradable edible films based on pea starch and guar gum', Industrial Crops \& Products. Elsevier B.V., 86, pp. 342-352. doi: 10.1016/j.indcrop.2016.04.015.

Sobral, P. J. A. (2015) 'Cellulose fiber reinforced biodegradable films based on proteins extracted from castor bean ( Ricinus communis L .) cake', Industrial Crops \& Products, 67, pp. 355-363. doi: 10.1016/j.indcrop.2015.01.036.

\section{Acknowledgment}

The authors thank the Brazilian National Council for Scientific and Technological Development (CNPq/Brazil) for granting a scholarship, Fundação Araucária and the Coordination for the Improvement of Higher Education Personnel (CAPES/Brazil). 